\title{
A 'black stomach' due to ingestion of anhydrous calcium chloride
}

\author{
Jose Maria Remes-Troche
}

Labortorio de Fisiologia Dlgestiva y Motilidad, Instituto de Investigaciones Medico Biologicas, Veracruz, Mexico

\section{Correspondence to}

Dr Jose Maria Remes-Troche, jose.remes.troche@gmail.com
To cite: Remes-Troche JM. BMJ Case Reports Published online: 2 January 2013 doi:10.1136/bcr-2012007716

\section{DESCRIPTION}

The accidental or suicidal ingestion of corrosives induces severe oesophagogastric damage that range from superficial erosions to perforation. The extension of the damage depends on several factors like the form of the substance (liquid, solid or gel), the $\mathrm{pH}$ of the substance (acid or alkaline), the amount ingested and duration of contact with the mucosa. The term 'black oesophagus' is the uncommon endoscopic finding of extensive black discolouration of the oesophageal mucosa, usually from acute oesophageal necrosis. ${ }^{1}$ Acute oesophagogastric necrosis is a rare clinical entity arising from a combination of ischaemic insult seen in low-flow states and corrosive injury. ${ }^{2}{ }^{3}$ Although there are some reports of acute gastric necrosis in the literature, we did not found any that described the endoscopic appearance of a 'black stomach'.

Here, we present a case of a 38 -year-old mentally disabled woman, due to hypoxic cerebral palsies at birth, who accidentally ingested $250 \mathrm{mg}$ of anhydrous calcium chloride granules, an alkaline substance. This compound is a dehumidifier to solve the problems of odour, rust and mildew stains caused by excess humidity. Two hours after the ingestion, the family found the patient vomiting and semiconscious. She was admitted to the emergency room with cardiovascular shock and metabolic acidosis. Conservative treatment with fluids, bowel rest, prophylactic antibiotics and continuous intravenous proton pump inhibitor. Twelve hours later, an upper gastrointestinal endoscopy was performed. In the distal oesophagus, an acute ulcer was found (figure 1A,B) and the entire stomach had a black appearance (figure 2A) due to massive mucosal necrosis. Note the appearance of the thrombosed gastric submucosal vessels (figure 2B). After 5 days, the patient died due to septic shock. The mechanism of the injury is related to the hygroscopic properties of the anhydrous calcium chloride granules; when theses granules dissolute produce an exothermic reaction. Because the

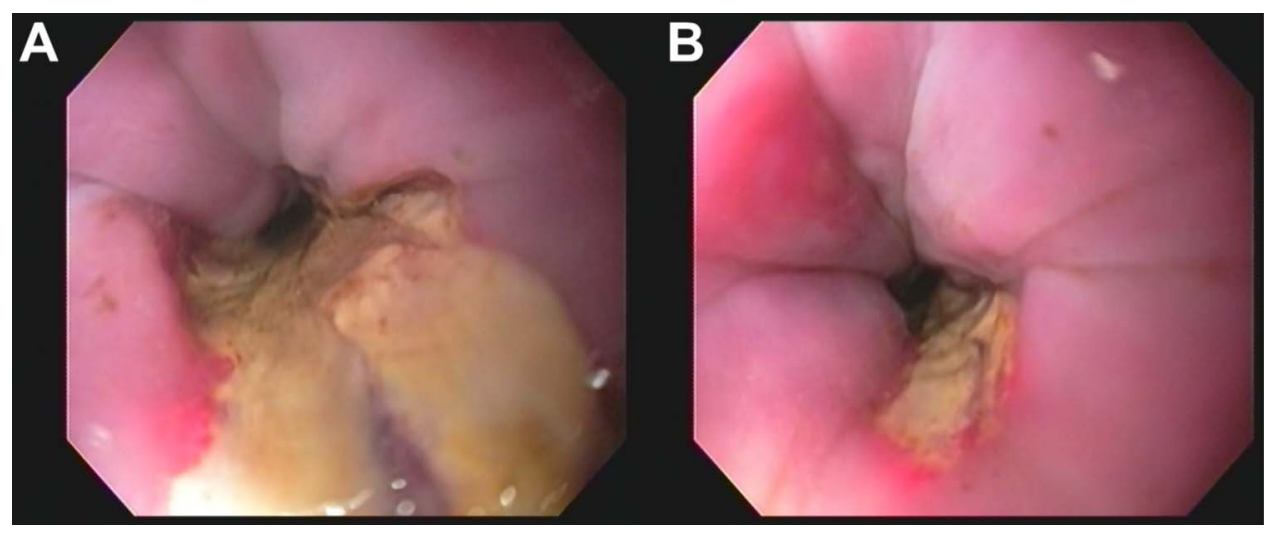

Figure 1 Acute ulcer in the distal oesophagus due to calcium chloride ( $\mathrm{A}$ and $\mathrm{B}$ ).

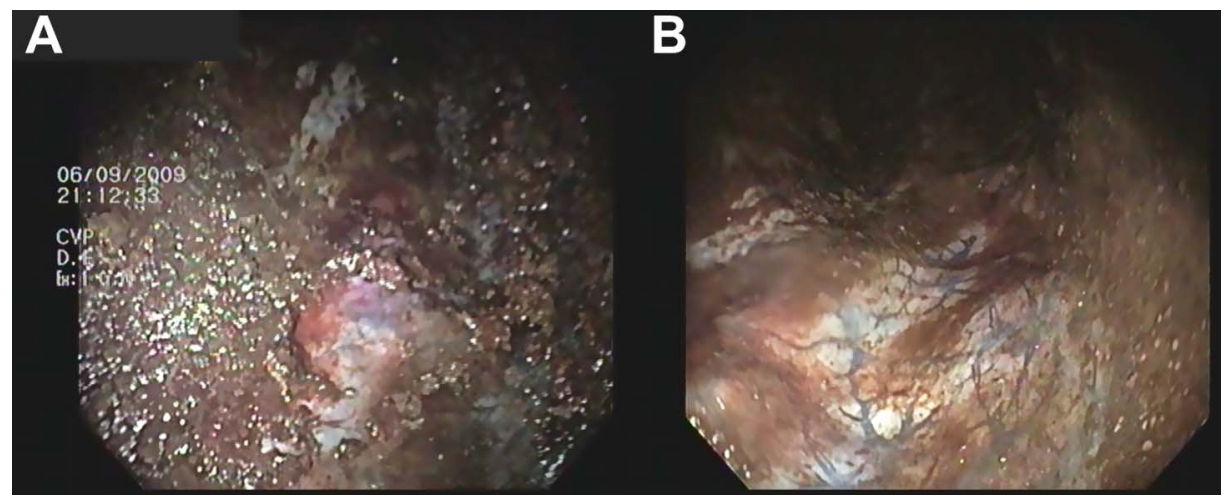

Figure 2 Black appearance of the stomach (A) due to massive mucosal necrosis. Note the blue appearance of the gastric submucosal vessels (B). 
stomach content have more water (ie, acid and mucus secretion) it seems that the burning was more severe than the oesophageal burn.

\section{Learning points}

- Acute oesophagogastric necrosis is a rare clinical entity arising from a combination of ischaemic insult seen in low-flow states and corrosive injury.

- The term 'black stomach' is the endoscopic finding of extensive black discolouration of the gastric mucosa, usually from acute necrosis.
Competing interests None.

Patient consent Obtained.

Provenance and peer review Not commissioned; externally peer reviewed.

\section{REFERENCES}

1 Kanaparthi C, Singhal S, Guillaume C, et al. Acute gastrointestinal necrosis: 'black esophagus' or 'black gut'. Trop Gastroenterol 2011;32:323-6.

2 Rejchrt $\mathrm{S}$, Douda T, Kopácová $\mathrm{M}$, et al. Acute esophageal necrosis (black esophagus): endoscopic and histopathologic appearance. Endoscopy 2004;36:1133.

3 Gurvits GE. Black esophagus: acute esophageal necrosis syndrome. World J Gastroenterol 2010;16:3219-25.

Copyright 2013 BMJ Publishing Group. All rights reserved. For permission to reuse any of this content visit http://group.bmj.com/group/rights-licensing/permissions.

BMJ Case Report Fellows may re-use this article for personal use and teaching without any further permission.

Become a Fellow of BMJ Case Reports today and you can:

- Submit as many cases as you like

- Enjoy fast sympathetic peer review and rapid publication of accepted articles

- Access all the published articles

- Re-use any of the published material for personal use and teaching without further permission

For information on Institutional Fellowships contact consortiasales@bmjgroup.com

Visit casereports.bmj.com for more articles like this and to become a Fellow 